\title{
Peran Liga Arab Pada Konflik di Timur Tengah Dalam Perspektif Ekonomi-Politik Internasional
}

\author{
Alifian Maulana Nanda Pradana \\ Universitas Islam Negeri Sunan Ampel Surabaya \\ email: pradanaalifian28@gmail.com \\ Dina Yulianti \\ Indonesia Center for Middle East Studies \\ Email: icmes.indonesia@gmail
}

\begin{abstract}
The Arab League since its establishment in 1945 has failed to play a significant role in minimizing conflicts in the region. In some contemporary conflicts (Syria and Yemen), it is the the powerful countries of the League that became the main actors in the conflict. This raises the question, what is the reason behind this failure, especially political-economic reasons. Using the literature review, this paper finds that there are two factors contributing to the failure, namely economic interdependence between rich Arab countries and the United States, and secondly, a strong relationship between the United States and Israel. The later becomes the reason why the US takes advantage of its economic hegemony to defend the interests of Israel.
\end{abstract}

Keywords: Arab League, US, Israel, political-economy, hegemony

\section{Abstrak}

Liga Arab yang didirikan sejak tahun 1945 hingga kini gagal dalam memainkan peran signifikan untuk meminimalisasi konflik di kawasan. Bahkan di beberapa konflik kontemporer (Suriah dan Yaman), justru negara-negara kuat di Liga Arab yang menjadi aktor dalam konflik tersebut. Hal ini memunculkan pertanyaan mengenaik apa alasan di balik kegagalan ini, terutama alasan ekonomipolitik. Dengan menggunakan kajian literatur, ditemukan dua faktor yang berperan dalam kegagalan itu, yaitu eratnya kerjasama ekonomi dan saling 
ketergantungan antara negara-negara kaya Arab dengan AS, dan yang kedua, adanya relasi kuat antara AS dan Israel sehingga AS memanfaatkan dominasi ekonominya di tengah negara-negara Arab untuk membela kepentingan Israel.

Kata kunci: Liga Arab, AS, Israel, ekonomi-politik, hegemoni

\section{Pendahuluan}

Timur Tengah seolah tak pernah lepas dari perang dan konflik. Selama beberapa dekade terakhir ada sejumlah perang yang terjadi di Timur Tengah, mulai dari Perang Iran-Irak (1980-1988), perang koalisi AS melawan Irak (1991 dan 2003), Perang Israel melawan warga Gaza (2008-2009, dan 2012), dan perang di Lebanon (1982, dan 2006). Sejak 2010, terjadi pula fenomena yang kerap disebut Arab Spring, dimulai dari penggulingan rezim di Tunisia (2010) dan Mesir (2011), penggulingan Qaddafi oleh milisi bersenjata lokal yang dibantu NATO (2011), dan perang berkepanjangan di Suriah (mulai 2011 hingga kini), serta agresi Arab Saudi ke Yaman (sejak 2015 hingga kini).

Kisruhnya Timur Tengah membuat sebagian pihak membuat pernyataan 'Dunia Lebih Damai Tanpa Timur Tengah', seolah sumber pergolakan ini adalah warga Timur Tengah sendiri. Sementara bila kita melakukan pelacakan aktor-aktor yang terlibat, kita bisa mendapati bahwa aktor terkuat dalam konflik-konflik di Timur Tengah adalah negara-negara Barat sebagai pemilik modal terkaya di dunia. Pergolakan politik baik internal maupun eksternal dari negara-negara Timur Tengah didasari oleh keinginan sebagian pihak, terutama pemodal, untuk menguasai sektor ekonomi utama yakni minyak dan gas. Namun, tak dipungkiri pula bahwa gelombang-gelombang konflik ini muncul di tengah rezim pemimpin yang tidak disukai sebagian rakyatnya. Ini menjadi dalih yang dipakai oleh negara adidaya untuk melakukan intervensi.

Misalnya, pada tahun 2003, AS dan koalisinya menyerang Irak dengan dalih untuk menggulingkan Saddam Husein yang berlaku diktator dan mengancam perdamaian dunia karena memiliki senjata pembunuh massal. ${ }^{1}$ Namun, keadaan di Irak pasca tumbangnya Saddam tidak membaik, melainkan terus dirundung konflik. Beberapa tahun terakhir bahkan warga Irak diserang oleh Islamic Statelraq and Syria (ISIS). Di sela-sela itu, korporasi-korporasi Amerikalah

1 Ansary, Tamim. 2012. Dari Puncak Baghdad. Jakarta: Serambi Ilmu Semesta. (524) 
yang mengambil keuntungan dari perang ini melalui kontrak-kontrak minyak dan rekonstruksi. Misalnya, Halliburton menagih dana ke pemerintah AS sebesar 17,2 Miliar US Dollar hanya dalam rentang waktu 3 tahun (20032006) untuk membiayai pembangunan dan pemeliharaan pangkalan militer, perbaikan ladang minyak, dan berbagai proyek pembangunan kembali infrastruktur. Atau, Washington Group Internasional yang memberikan jasa memperbaiki dan merawat lading-ladang minyak, selama 200-2006 saja telah mendapatkan uang sebesar 931 juta US Dollar. ${ }^{2}$

Konflik yang saat ini masih berkembang adalah konflik Suriah. Diawali dengan tuduhan sebagian pihak bahwa Bashar Assad adalah rezim yang korup dan diktator, muncul milisi-milisi bersenjata yang didukung negaranegara Arab dan AS, Inggris, serta Perancis. Mereka melakukan serangan bersenjata dan pengeboman, yang dihadapi juga dengan senjata oleh tentara pemerintah. Akibatnya, rakyat sipil menjadi korban dan mengungsi ke berbagai negara di sekitar, maupun ke Eropa. Perang Suriah kini melibatkan banyak aktor, mulai dari pemerintah Suriah, negara-negara Arab/Teluk, AS, Turki, Rusia, Iran, dan non-state actors teroris seperti Hizbullah (Lebanon), ISIS, Jabhah Al Nusra, Ahrar al Syam, dan lain-lain.

Di tengah semua konflik ini, muncul pertanyaan, dimanakah peran Liga Arab? Apakah ada kaitan antara faktor ekonomi-politik dengan kemandulan Liga Arab dalam meminimalisasi konflik di Timur Tengah? Artikel ini akan berusaha menjawabnya melalui kajian literatur.

\section{Sejarah Liga Arab}

Liga Arab didirikan pada bulan Maret 1945 oleh 22 negara Arab, termasuk Palestina, dengan misi untuk menjalin koordinasi di antara negaranegara tersebut. Menurut Piagam Liga Arab, negara-negara pendiri, yaitu Mesir, Suriah, Jordania, Irak, Arab Saudi, Lebanon, dan Yaman sepakat untuk melakukan kerjasama yang erat di bidang ekonomi, komunikasi, budaya, kesehatan, dan lain-lain.

2 Bussinesspundit.com. 2008. "Iraq War Profiteers: 25 Companies Who Benefit From The War". Melalui <http://www.huffingtonpost.com/2008/07/25/iraq-war-profiteers-25co_n_115004.html >[5/6/2017] 
Kerjasama ekonomi ini dipandang penting karena kondisi ekonomi negara-negara anggota Liga Arab sangat beragam, mulai dari yang amat kaya raya hingga amat miskin. Berikut ini daftar negara anggota Liga Arab dengan jumlah populasi dan GDP-nya: ${ }^{3}$

\begin{tabular}{|c|c|c|c|}
\hline No & Nama Negara & Populasi & $\begin{array}{l}\text { GDP (dalam juta USD) dan } \\
\text { Rankingnya di Dunia }\end{array}$ \\
\hline 1 & Aljazair & 39.667 .000 & 164.779 (rangking 54) \\
\hline 2 & Arab Saudi & 31.540 .000 & $646.002(20)$ \\
\hline 3 & Bahrain & 1.377 .000 & $31.126(96)$ \\
\hline 4 & Djibouti & 888.000 & $1.727(173)$ \\
\hline 5 & Komoro & 788.000 & $566(190)$ \\
\hline 6 & Kuwait & 3.892 .000 & $114.041(57)$ \\
\hline 7 & Irak & 36.423 .000 & $177.954(51)$ \\
\hline 8 & Lebanon & 5.851 .000 & $47.085(82)$ \\
\hline 9 & Libya & 6.278 .000 & ... [tidak ada data] \\
\hline 10 & Mauritania & 4.068 .000 & $5.442(154)$ \\
\hline 11 & Maroko & 34.378 .000 & $100.593(60)$ \\
\hline 12 & Mesir & 91.508 .000 & $330.779(31)$ \\
\hline 13 & Oman & 4.491 .000 & $69.831(67)$ \\
\hline 14 & Palestina & ... [tidak ada data] & ... [tidak ada data] \\
\hline 15 & Qatar & 2.235 .000 & $164.641(55)$ \\
\hline 16 & Somalia & 10.787 .000 & $5.734(151)$ \\
\hline 17 & Sudan & 38.435 .252 & $97.156(62)$ \\
\hline 18 & Suriah & 18.502 .000 & ... [tidak ada data] \\
\hline 19 & Tunisia & 11.254 .000 & $43.015(85)$ \\
\hline 20 & Uni Emirat Arab & 9.157 .000 & $370.296(30)$ \\
\hline 21 & Yordania & 7.595 .000 & $37.517(90)$ \\
\hline 22 & Yaman & 26.832 .000 & $37.734(88)$ \\
\hline
\end{tabular}

Sumber tabel: Bank Dunia (2015)

3 GDP (Gross Domestic Product) atau Produk Domestik Bruto adalah total nilai produksi barang dan jasa di dalam suatu negara selama satu tahun, yang meliputi juga pendapatan yang dihasilkan penduduk asli dan perusahaan asing di dalam negara yang bersangkutan. Salah satu indikator pertumbuhan ekonomi suatu negara dihitung dari total GDP dibagi populasi (=GDP per kapita).

4 World Bank. 2015. "Gross Domestic Product 2015". Melalui <http://databank. 
Dari tabel di atas dapat dilihat bahwa negara-negara Liga Arab yang memiliki pendapatan tinggi adalah Arab Saudi, Bahrain, Kuwait, Qatar, dan Uni Emirat Arab. Negara-negara ini penghasilan utamanya didapat dari ekspor minyak dan gas. Di antara kelima negara ini, negara dengan total GDP terkaya adalah Arab Saudi, namun Qatar menjadi negara yang paling tinggi pertumbuhan ekonominya karena populasinya yang hanya sekitar dua juta.

Lebanon, Libya, dan Oman dikategorikan negara dengan pendapatan menengah ke atas (upper middle-income). Namun sejak tergulingnya Qaddafi pada 2011, kondisi Libya semakin memburuk. Pada yang pada 2009, Libya memiliki total GDP 63 Miliar US Dollar atau GDP perkapita sebesar 10.151,65 US Dollar. Namun kini diperkirakan sudah anjlok ke angka 29 Miliar US Dollar. ${ }^{5}$ Sementara itu, negara dengan pendapatan menengah-ke bawah (low-middle income) adalah Aljazair, Djibouti, Mesir, Yordania, Maroko, Suriah, dan Tunisia. Total GDP Mesir sebenarnya juga tinggi dan berada di ranking ke-31 dunia, namun tingginya populasi, angka kemiskinan, dan jumlah pengangguran membuat Mesir tergolong ke dalam negara berpendapatan rendah. Sedangkan negara-negara yang termasuk ke dalam kategori miskin adalah Mauritania, Sudan, dan Yaman. ${ }^{6}$

Struktur institusional Liga Arab terdiri dari 3 badan utama, yaitu Dewan (the Council), Sekretariat Permanen, dan sejumlah Komite Permanen. Semua negara anggota memiliki satu kursi dan satu suara dalam Dewan dan sidang Dewan Liga Arab dilaksanakan dua kali setahun. Keputusan yang diambil hanya mengikat negara-negara yang menyetujui keputusan itu. Dewan Liga Arab memiliki kewajiban untuk mengintervensi konflik yang berpotensi memicu perang antaregara anggota. Pada tahun 1950, Liga Arab menyepakati perjanjian militer, bahwa agresi terhadap satu negara Arab berarti agresi terhadap seluruh anggota dan akan dihadapi bersama-sama.

Namun di sisi lain, ada aturan bahwa Liga dilarang menggunakan kekuatan militer di antara negara anggota. Di pasal yang lain juga disebutkan bahwa

worldbank.org/data/download/GDP.pdf> dan "Population 2015" melalui <http://databank.worldbank.org/data/download/POP.pdf> [7/6/2017]

5 Data GDP Libya tahun 2009 dan 2015. Melalui <https://www.google. com/publicdata/explore?ds=d5bncppjof8f9_\&met_y=ny_gdp_mktp_ cd\&idim=country:LBY:TUN:MAR\&hl=id\&dl=id > [15/6/2017]

6 El Shenawi. 2011. "Poking at the Beast: How much is the Arab world worth?" Melalui <http://english.alarabiya.net/articles/2011/05/05/147980.html> [15/6/2017] 
jika ada aksi agresi di antara negara anggota, Liga harus menghadapinya dengan persetujuan semua anggota. Di sini ada kontradiksi, apakah aksi agresi boleh dihadapi dengan senjata, sementara di pasal yang sebelumnya disebutkan pelarangan penggunaan senjata. Namun dengan aturan-aturan yang ada, sejauh ini Liga Arab berhasil memediasi 12\% konflik yang terjadi di Dunia Arab, meski hanya 7 dari 77 konflik yang berhasil diselesaikannya dalam periode 1945-1981.?

Dalam perkembangannya, justru Liga Arab memberikan persetujuan bagi eskalasi konflik di dalam negara anggotanya. Misalnya, pada tahun 2011, Liga Arab menyetujui no-fly zone di Libya. Pemberlakuan no-fly zone berujung pada serangan NATO ke Libya dan penggulingan Muammar al-Qaddafi. Akibatnya negeri di timur laut benua Afrika itu kini terjebak dalam konflik sipil berkepanjangan. Liga Arab juga mendukung agenda pergantian rezim di Suriah dan mencabut keanggotaan Suriah di Liga Arab pada 16 November 2011 dengan tuduhan bahwa Assad melakukan kekerasan terhadap demonstran di negaranya.

Konflik berkepanjangan di Timur Tengah membuat para penduduk di kawasan ini (terutama Libya, Suriah, Irak) banyak yang harus mengungsi ke beberapa negara di Eropa. Hal yang ironis, negara-negara kaya di Liga Arab sendiri menolak menerima kehadiran para pengungsi itu dengan berbagai macam alasan. Menurut data UNHCR, negara-negara yang menampung para pengungsi dalam konflik era Arab Spring adalah negara-negara dengan kondisi ekonomi relatif lemah, yaitu:

- Lebanon menampung 1,1 juta pengungsi ( $26 \%$ dari populasi negara itu)

O Yordania menampung 618.615 pengungsi (9.8\% dari populasi negara itu)

O Turki menampung 1,6 juta pengungsi (2.4\% dari populasi negara itu)

$7 \quad$ Nasur, et al. 2017. "The Failure of the Arab League in Solving Inter-State Disputes". Melalui < http://www.bjournal.co.uk/volume/paper/BJASS_22_1/BJASS_22_01_02. pdf $>[6 / 6 / 2017]$ 
O Irak menampung 225.373 pengungsi (0.67\% dari populasi negara itu)

O Mesir menampung 142.543 pengungsi (0.17\% dari populasi negara itu).

Absennya negara Arab yang makmur seperti Bahrain, Kuwait, Qatar, Uni Emirat Arab, dan Arab Saudi dalam menampung pengungsi semakin memperjelas bahwa pelaksanaan diplomasi politik Liga Arab masih sangat buruk.

Catatan prestasi Liga Arab dalam resolusi konflik yang berupa perang sipil secara umum mengecewakan. Organisasi ini awalnya didirikan untuk menjaga kedaulatan masing-masing negara anggotanya. Namun, sejauh ini Liga Arab hanya melakukan mediasi pada 5 dari 22 perang sipil besar yang terjadi di kawasan sejak 1945. Kegagalan ini biasanya terjadi akibat ketidakefisienan organisasi ini dalam pengambilan keputusan. Misalnya, pada 4 April 1958, Liga Arab menyetujui draft resolusi dalam Perang Lebanon pertama, namun akhirnya gagal disahkan dalam resolusi akhir. Lalu, persaingan antarnegara membuat Sidang Liga Arab tahun 1964 yang membahas perang sipil di Yaman membuat sidang tidak berhasil mencapai kesepakatan, padahal Liga Arab sudah mengirimkan misi pencari fakta ke Yaman pada Oktober 1963. Ketika Perang Lebanon kedua terjadi tahun 1975, Liga Arab hanya mampu menyerukan agar semua pihak bersikap bijak dan menahan diri. Secara umum ada sikap tidak ingin mencampuri urusan domestik negara lain dengan harapan untuk menjaga perbatasannya sendiri agar tidak dicampuri pihak lain pula. ${ }^{8}$

Berikut ini sejumlah peran yang dilakukan Liga Arab dalam resolusi konflik di Timteng. ${ }^{9}$

1. Mengirimkan Pasukan Perdamaian dalam konflik Irak-Kuwait tahun 1961. Saat itu, segera setelah Kuwait mengumumkan

$8 \quad$ Nasur, et al. 2017. "The Failure of the Arab League in Solving Inter-State Disputes". Melalui < http://www.bjournal.co.uk/volume/paper/BJASS_22_1/BJASS_22_01_02. pdf $>[6 / 6 / 2017]$

9 Youssef, Hesham. tt. "Mediation and Conflict Resolution in the Arab World: The Role of the Arab League". Melalui <https://ifsh.de/file-CORE/documents/yearbook/english/13/ Youssef-en.pdf> [3/6/207] 
kemerdekaannya, Irak mengklaim sejumlah wilayah Kuwait sebagai bagian dari wilayahnya (kepulauan Warbah dan Bubiyan. Sebagai balasan, Inggris memobilisasi pasukan untuk melawan Irak. Pasukan Liga Arab berperan melindungi Kuwait dan Inggris pun keluar dari wilayah itu. Pada 1963, akhirnya Irak mengakui kemerdekaan Kuwait.

2. Mengirimkan "Pasukan Penyeimbang Arab" ke Lebanon tahun 1976, terdiri dari Libya, Saudi, Arabia, Yemen Selatan, Sudan, Suriah, dan Uni Emirat Arab. Tujuan pasukan ini adalah untuk mendamaikan perang sipil yang terjadi di Lebanon.

3. Mengambil keputusan menentang invasi Irak ke Kuwait tahun 1990. Liga Arab berupaya menekan Irak agar mundur dari Kuwait namun upaya ini gagal sampai akhirnya dibentuk pasukan koalisi AS (beranggotakan sejumlah anggota Liga Arab, yaitu Mesir, Suriah, Maroko, dan negara Teluk) untuk membebaskan Kuwait.

4. Pada 2011, membentukmisi peninjau (ObserverMission) keSuriah dan menandatangani perjanjian dengan Suriah, pada 19 December 2011 untuk memfasilitasi pekerjaan misi tersebut. Di antaranya, mencegah terjadinya jatuh korban di pihak sipil, melindungi kedatangan jurnalis asing, dan mencegah tentara Suriah mengambil tindakan atas aksiaksi demo. Namun misi dihentikan pada 26 Januari 2012, seiring dengan semakin banyaknya aksi bom bunuh diri di Suriah yang dilakukan militan. Dan akhirnya, Suriah dicabut keanggotaannya dari Liga Arab. Secara resmi Liga Arab mendukung penggulingan Assad. Bahkan negara-negara anggota Liga Arab, seperti Arab Saudi dan Qatar merupakan penyuplai utama dana dan senjata untuk milisimilisi bersenjata yang bertempur menggulingkan Assad.

5. Liga Arab berupaya memediasi konflik di Yaman, dimana kelompokkelompok demonstran, antara lain Houthi dan kelompok Sufi menuntut reformasi politik dan ekonomi. Namun mediasi ini tidak berhasil. Presiden Ali Abdullah Saleh dan penggantinya kemudian melarikan diri ke Saudi dan meminta bantuan militer. Sejak 2015, Arab Saudi melakukan serangan udara ke Yaman dan mengakibatkan kematian puluhan ribu rakyat sipil. Liga Arab sama sekali tidakmampu 
melakukan resolusi konflik, atau setidaknya mengecam Arab Saudi yang telah melakukan agresi dan pelanggaran hukum internasional terhadap Yaman, serta pelanggaran atas konstitusi Liga Arab sendiri.

Dalam sidang tahunan Maret 2017 di Jordania, Liga Arab mengeluarkan final communique yaitu dukungan total kepada kemerdekaan Palestina dengan Jerusalem sebagai ibu kotanya, menentang pembangunan permukiman Israel dan upaya Israel untuk menguasai Jerusalem sepenuhnya. ${ }^{10}$ Namun hal ini dipandang banyak pihak sebagai sekedar lip service karena sudah 69 tahun berdirinya Israel namun negara-negara Arab tidak mampu menolong Palestina meraih haknya. Selain itu, konflik di antara negara-negara Arab semakin memanas, terutama di Suriah dan Yaman, tanpa mampu diselesaikan oleh Liga Arab.

Penulis mengidentifikasi ada dua faktor yang berperan penting dalam kegagalan Liga Arab dalam melaksanakan tujuan-tujuan organisasi ini, yaitu sebagai berikut.

\section{Faktor Pertama: Kepentingan Ekonomi AS-Arab}

Kawasan Timur Tengah merupakan kawasan yang sangat kaya sumber daya minyak dan gas. Pada tahun 2007, kawasan ini memproduksi 36,7\% total produksi minyak mentah dunia. Hal ini menjadi sumber ketergantungan negara-negara Barat, terutama AS, terhadap Timur Tengah dan karena itulah kebijakan luar negeri AS pasca Perang Dunia II sangat memberikan prioritas terhadap keamanan aset minyak di Timur Tengah dan jalur distribusinya.

Ada 3 komponen pendekatan AS terhadap keamanan minyak di Timur Tengah, yaitu:

1. Sejak tahun 1971, AS terus mempertahankan kehadiran angkatan lautnya di Teluk Persia demi menjaga keamanan distribusi minyaknya. Sebelum Revolusi Islam Iran tahun 1979, kehadiran angkatan laut AS di Teluk Persia berkoordinasi dengan pemerintah Iran dan Arab Saudi, yang disebut dengan 'kebijakan dua pilar'. Namun setelah hubungan

10 Al-monitor.com. 2017. "Palestine tops Arab League agenda at Jordan summit". Melalui $<$ http://www.al-monitor.com/pulse/originals/2017/03/arab-league-summit-palestinetwo-state-solution.html\#ixzz4iRzAWA6F> [6/6/2017] 
AS-Iran memburuk pasca revolusi Iran, AS semakin memperkuat militernya di kawasan, dan kehadiran militer AS semakin intensif pasca Perang Teluk pertama tahun 1990-1991.

2. AS menjalin kerjasama yang erat dengan negara-negara kerajaan yang memiliki cadangan minyak yang besar, yaitu Arab Saudi, Kuwait, Bahrain, Qatar, Oman, dan Uni Emirat Arab.

3. AS memaksimalkan kehadiran perusahaan-perusahaan minyak AS dalam proyek-proyek eksplorasi, refinasi, dan transportasi minyak dan gas di kawasan. Perusahaan-perusahaan minyak Barat seperti Halliburton, ExxonMobil, Texaco, dan British Petroleum (yang sebagian besar sahamnya dimiliki AS) merupakan perusahaanperusahaan yang sangat mendominasi di Timur Tengah. ${ }^{11}$

Keenam negarayang disebutkan sebelumnya (Arab Saudi, Kuwait, Bahrain, Qatar, Oman, dan Uni Emirat Arab) tergabung dalam Gulf Cooperation Council (GCC) yang dibentuk tahun 1981. Keenam negara ini merupakan negara dengan pendapatan per kapita tertinggi di Timur Tengah (lihat Diagram 1).

\section{Diagram 1: Pendapatan Perkapita Negara-Negara Arab}

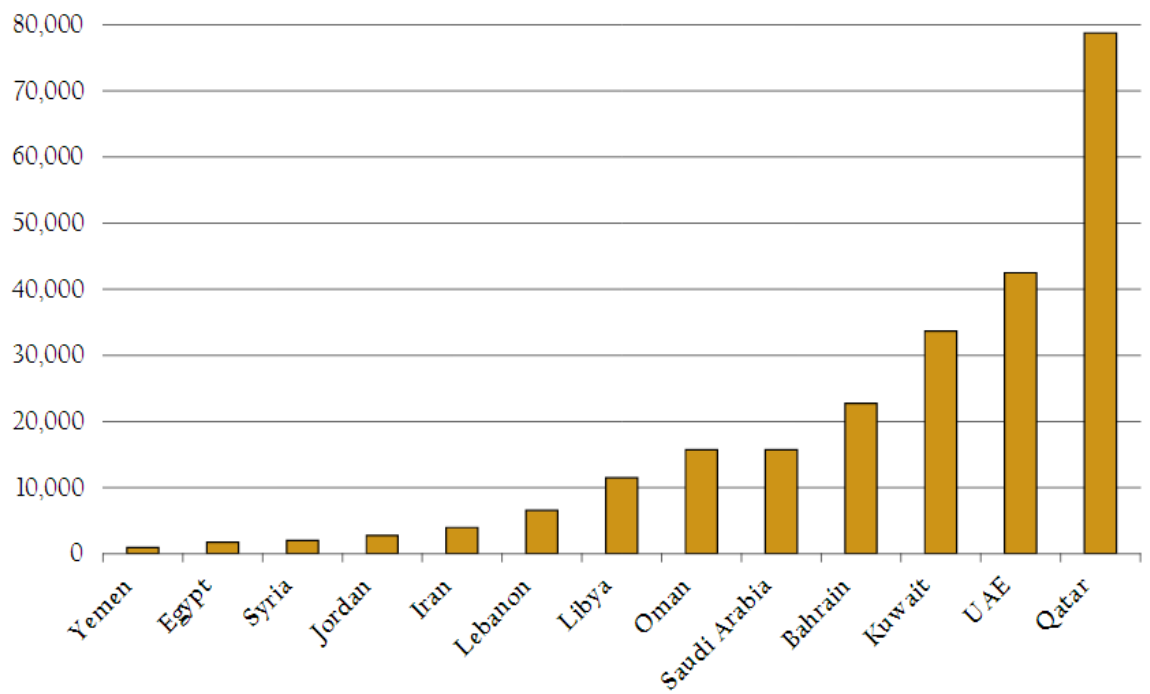

11 Habibi and Woertz. 2009. "US - Arab Economic Relations and the Obama Administration". Melalui <http://www.brandeis.edu/crown/publications/meb/MEB34.pdf> [6/6/2017] 
Sumber tabel: Habibi and Woertz (2009) ${ }^{12}$

Seiring dengan meningkatnya pertumbuhan ekonomi di negara-negara Arab berkat minyak, jumlah barang-barang yang diimpor mereka pun semakin meningkat (Diagram 2). Selain itu, juga terjadi peningkatan investasi di bidang real estate, infrastruktur, dan manufaktur. Negara-negara pengekspor barangbarang kebutuhan Timur Tengah terbesar adalah AS, Eropa, dan China.

\section{Diagram 2: Volume Impor Barang dari AS oleh negara-negara Arab (juta USD)}



Sumber tabel: Habibi and Woertz (2009) ${ }^{13}$

Jika dari sisi minyak dan gas negara-negara Barat, terutama AS, bergantung kepada negara-negara GCC, sebaliknya, GCC ini juga bergantung kepada AS dalam urusan pertahanan dan keamanan. Mereka adalah pengimpor terbanyak senjata-senjata produksi AS. Selama 4 tahun pertama era Arab Spring (2011-2015), GCC mengimpor senjata 200 persen lebih banyak. Arab Saudi dan Qatar merupakan negara yang peningkatan impor senjatanya terbesar. Impor senjata Arab Saudi periode 2011-2015 meningkat 275\% dibandingkan impor yang dilakukannya pada periode 2006-2010. Dalam 
periode yang sama, impor senjata Uni Emirat Arab meningkat 35\% dan Qatar $279 \% .{ }^{14}$

Dalam kunjungan Presiden AS, Donald Trump, ke Arab Saudi pada bulan Mei 2017, disepakati perjanjian penjualan senjata AS ke Arab Saudi senilai 350 miliar USD dalam jangka waktu 10 tahun, dimana pembelian senilai 110 miliar USD akan segera direalisasikan. Di samping itu, Arab Saudi juga menandatangi perjanjian dengan perusahaan-perusahaan swasta AS, yang merupakan bagian reformasi ekonomi Saudi dalam upaya melepaskan diri dari ketergantungan pada pendapatan di sektor minyak. Di antara kontrak senilai puluhan miliar USD ini adalah kontrak dengan perusahaan militer Lockheed Martin, yang menjanjikan proyek bersama yang dapat membuka lapangan pekerjaan bagi ribuan tenaga kerja ahli.

Dari data-data di atas kita bisa melihat besarnya keterikatan ekonomi antara negara-negara besar Arab (GCC) dengan Barat. Di saat yang sama, konflik-konflik di Timur Tengah sangat berkaitan dengan kepentingan AS dan Israel, sebagaimana yang akan diuraikan berikut ini.

\section{Faktor Kedua: Relasi AS-Israel}

Peta konflik di Timur Tengah sejak 2010 mengalami pergeseran penting. Bila sebelumnya, secara garis besar ada dua kubu yang berseteru, yaitu Israel versus negara-negara Arab, namun kini yang terjadi adalah peperangan di antara sesama negara Arab dengan menggunakan proxy. Contoh kasus yang paling jelas bisa dilihat dalam konflik Suriah. Dalam tabel berikut ini dipetakan siapa lawan-kawan dalam konflik ini.

\begin{tabular}{|l|l|l|l|}
\hline $\begin{array}{l}\text { Pendukung } \\
\text { Intervensi } \\
\text { Militer ke } \\
\text { Suriah }\end{array}$ & Keterangan & $\begin{array}{l}\text { P e n o I a k } \\
\text { Intervensi } \\
\text { Militer ke } \\
\text { Suriah }\end{array}$ & Keterangan \\
\hline AS & $\begin{array}{l}\text { Memberikan bantuan } \\
\text { senjata kepada pasukan } \\
\text { pemberontak }\end{array}$ & Rusia & $\begin{array}{l}\text { Membantu Suriah mela- } \\
\text { wan ISIS. }\end{array}$ \\
\hline
\end{tabular}

14 Alaraby.co.uk. 2016. "Gulf States Increase Arms Imports 200\%". Melalui <https://www. alaraby.co.uk/english/news/2016/2/23/gulf-states-increase-arms-imports-by-200percent $>$ [8/6/2017] 


\begin{tabular}{|c|c|c|c|}
\hline Inggris & $\begin{array}{l}\text { Memberikan bantuan } \\
\text { dana kepada White Hel- } \\
\text { mets }\end{array}$ & China & $\begin{array}{l}\text { Membantu Suriah mela- } \\
\text { wan ISIS }\end{array}$ \\
\hline Perancis & $\begin{array}{l}\text { Memberikan bantuan } \\
\text { senjata kepada pasukan } \\
\text { pemberontak }\end{array}$ & Iran & $\begin{array}{l}\text { Membantu Suriah mel- } \\
\text { awan ISIS dan berbagai } \\
\text { kelompok pemberontak. }\end{array}$ \\
\hline Israel & $\begin{array}{l}\text { Melakukan serangan } \\
\text { udara ke Suriah. }\end{array}$ & $\begin{array}{l}\text { L e b a n o n } \\
\text { (Hizbullah) }\end{array}$ & $\begin{array}{l}\text { Membantu Suriah mel- } \\
\text { awan ISIS dan berbagai } \\
\text { kelompok pemberontak. }\end{array}$ \\
\hline Arab Saudi & $\begin{array}{l}\text { Memberikan bantuan } \\
\text { senjata kepada pasukan } \\
\text { pemberontak }\end{array}$ & Yordania & $\begin{array}{l}\text { Menutup perbatasan se- } \\
\text { hingga tidak bisa dilalui } \\
\text { kelompok militan, namun } \\
\text { tetap bekerja sama den- } \\
\text { gan AS dalam melatih } \\
\text { militan Suriah. }\end{array}$ \\
\hline Qatar & $\begin{array}{l}\text { Memberikan bantuan } \\
\text { senjata kepada pasukan } \\
\text { pemberontak }\end{array}$ & Mesir & $\begin{array}{l}\text { Menolak intervensi militer } \\
\text { ke Suriah, namun tetap } \\
\text { berkoalisi dengan AS dan } \\
\text { Saudi. }\end{array}$ \\
\hline Turki & $\begin{array}{l}\text { Memberikan bantu- } \\
\text { an senjata dan logistik } \\
\text { kepada pasukan pem- } \\
\text { berontak. }\end{array}$ & & \\
\hline
\end{tabular}

\section{Sumber tabel: diadaptasi dari diagram Katie Gould ${ }^{15}$}

Dari tabel di atas, kita melihat bahwa negara-negara anggota Liga Arab bergabung atau mendukung agenda penggulingan rezim Assad (terkecuali Lebanon, dimana milisi bersenjata yang direstui pemerintah, Hezbollah, memberikan dukungan langsung kepada militer Suriah). Dengan demikian, mayoritas negara-negara Liga Arab berada di bawah hegemoni negaranegara adidaya, dalam arti bekerjasama dan beraliansi bersama AS, Inggris, dan Perancis. Negara-negara Arab yang seharusnya menjalin kekuatan

15 Gould, Katie. 2013. "Connecting Syria's allies and enemies". Melalui <http://www.pbs. org/newshour/extra/lessons_plans/understanding-different-sides-syrian-conflict/> [7/6/2017] 
bersama dalam Liga Arab dan melindungi sesama anggotanya dari agresi asing, kini bergabung dengan kekuatan adidaya yang berkepentingan untuk menggulingkan rezim Assad.

Hal ini kemudian memunculkan pertanyaan, apa yang melatarbelakangi keinginan Barat untuk menggulingkan pemerintah Suriah yang dipilih secara demokratis melalui pemilu? Bila jawabannya adalah demokrasi, tentu kontradiktif dengan peta aliansi konflik dimana Barat justru bekerja sama dengan negara-negara nondemokratis seperti Arab Saudi, Qatar, dan Yordania. Untuk mendapatkan jawabannya, kita perlu melihat profil sistem demokrasi di Barat, terutama AS.

Telah menjadi rahasia umum bahwa pemerintah AS sangat dipengaruhi oleh faksi-faksi pro-Israel di dalam negeri. ${ }^{16}$ Dalam sistem demokrasi di AS (dan negara-negara demokrasi liberal lainnya), uang memiliki peran yang amat signifikan. Para politisi di AS sangat membutuhkan dana dan pemilik terbesar sumber-sumber keuangan di AS adalah pengusaha-pengusaha Zionis AS. Menurut Center for Responsive Politics, Obama secara tak langsung menerima sumbangan sebesar 213.000 US Dollar dari perusahaan minyak dan gas. Politisi lainnya, seperti Hillary Clinton juga mendapatkan sumbangan, yaitu sekitar 300.000 US Dollar, sementara John McCain 1,3 juta US Dollar. Dengan 'sumbangan' yang diberikan kepada para kandidat presiden dan anggota Kongres, Big Oil (julukan bagi perusahaan-perusahaan minyak multinasional) meraup keuntungan yang jauh lebih banyak lagi. Pemerintah AS (dengan disetujui Kongres) memberikan banyak insentif dan subsidi kepada Big Oil. Pada tahun 2007 mereka meraup laba 123 milyar dollar, padahal di saat yang sama, mereka mendapatkan subsidi, insentif, dan pengurangan pajak sebesar 32,9 milyar dollar yang disediakan oleh pemerintah AS. ${ }^{17}$

Oleh karena itu pula kebijakan-kebijakan AS di Timur Tengah juga sangat menguntungkan perusahaan-perusahaan Big Oil ini. Dan lebih jauh lagi, kepemilikan saham perusahaan-perusahaan tersebut adalah para pengusaha Zionis pro-Israel, sehingga Israel pun merupakan faktor utama mengapa kebijakan luar negeri AS selalu mengobarkan konflik di Timur Tengah.

16 M. Riza Shihbudi, Timur Tengah, Dunia Islam, dan Hegemoni Amerika, (Malang: Pustaka Hidayah, 1993), 45

17 Sulaeman, Dina. 2008. “Obama Revealed”. Jakarta: Aliya Publishing. (130) 
Hal ini disampaikan dua pakar politik dari University of Chicago dan Harvard Universtiy, John J. Mearsheimer dan Stephen M. Walt dalam makalah mereka The Israel Lobby and US Foreign Policy:

"Washington tidak akan mengkhawatirkan Iran, Partai Baath Irak, atau Syria jika saja AS tidak sedemikian terikat dengan Israel. Bahkan bila negara-negara itu memiliki senjata nuklir-tentu saja hal ini tidak diinginkan-mereka bukanlah ancaman strategis bagi AS. ...Lebih jauh lagi, hubungan AS dengan Israel sesungguhnya membuat AS sulit menghadapi negara-negara itu. Senjata nuklir Israel menjadi alasan mengapa sebagian tetangga Israel ingin memiliki senjata nuklir dan ancaman AS terhadap negara-negara itu berkaitan dengan 'perubahan rezim,' justru meningkatkan keinginan itu. ...Kombinasi dari dukungan kukuh AS kepada Israel dan usaha untuk menyebarkan demokrasi di kawasan telah membakar [amarah] dunia Arab dan Islam, dan membahayakan keamanan AS."18

Mas'oed menyatakan, "Sesudah power, national interest (kepentingan nasional) adalah konsep yang paling populer dalam analisa hubungan internasional, baik untuk mendeskripsikan, menjelaskan, meramalkan, maupun menganjurkan perilaku internasional. Analis sering memakai konsep 'kepentingan nasional' sebagai dasar untuk menjelaskan perilaku luar negeri suatu negara." ${ }^{19}$

'Kepentingan nasional' ini pula yang selama ini dipakai oleh para petinggi AS dalam menjustifikasi pembelaan mereka terhadap Israel. Obama dalam pidatonya di depan AIPAC (organisasi lobby Yahudi terbesar di AS) menyebut 'kesamaan kepentingan' sebagai landasan politik luar negerinya terhadap Israel.

"Aliansi kita [AS-Israel] berdasarkan pada kesamaan kepentingan dan kesamaan nilai-nilai. Siapa yang mengancam Israel, mengancam kita. Israel selalu menghadapi ancaman-ancaman itu digaris depan. Dan saya akan membawa Gedung Putih ke arah komitmen yang tak tergoyahkan

18 Mearsheimer, John J. and Walt, Stephen M. 2006. "The Israel Lobby and US Foreign Policy". London Review of Books Vol. 28, No. 6: 5

19 Mas'oed, Mohtar. 2009. Ilmu Hubungan Internasional. Jakarta: LP3ES. (139) 
bagi keamanan Israel. Komitmen ini dimulai dengan menjamin bantuan militer Israel. Saya akan menjamin bahwa Israel dapat membela diri dari segala ancaman, dari Gaza hingga Teheran." 20

Dalam kunjungannya ke Arab Saudi bulan Mei 2017, Presiden AS, Donald Trump menyebut Iran sebagai negara pendukung terorisme dan penyebab instabilitas di kawasan, tanpa sama sekali menyebut Israel yang terus melakukan kejahatan kemanusiaan di Palestina dan terlibat dalam upaya penggulingan rezim di Suriah dan agresi Arab Saudi di Yaman. Dalam pidatonya menyambut kedatangan Netanyahu ke Gedung Putih, Trump menegaskan bahwa hubungan antara AS dan Israel adalah unbreakable bond.

Dengan demikian, tujuan kebijakan luar negeri AS terhadap negaranegara Timur Tengah ada dua, yaitu menjaga keamanan suplai minyak dan menjaga kepentingan Israel. Dalam implementasinya, AS melakukan politik adu-domba di antara kekuatan-kekuatan internal negara-negara Arab. Selama tahun 1950-an, Presiden Eisenhower dan saudara Dulles bersaudara (Direktur CIA Allen Dulles dan Menteri Luar Negeri John Foster Dulles) mendalangi perang klandestin melawan kekuatan nasionalisme Arab yang mengancam suplai minyak untuk AS. Mereka memberikan bantuan militer rahasia kepada kelompok-kelompok tiran di Arab Saudi, Yordania, Irak dan Lebanon. Pada tahun 1957, Presiden Eisenhower memberikan saran kepada CIA, "Kita harus melakukan segala kemungkinan untuk menekankan sisi 'perang suci,', hal ini dicatat dalam memo sekretarisnya, Jenderal Andrew J. Goodpaster. ${ }^{21}$

Perang suci alias jihad ini telah menjadi 'senjata' yang dimanfaatkan oleh AS dalam menghadapi Uni Soviet. Mereka merekrut petempur Muslim untuk berperang melawan Soviet. Hal ini diuraikan oleh Prof. Michel Chossudovsky dalam bukunya, “America's War on Terrorism” (2005). Berikut ini beberapa kutipan data yang dikumpulkannya:

"AS menghabiskan milyaran dolar untuk menyuplai sekolah-sekolah di Afghanistan dengan buku-buku teks berisi gambar-gambar kekerasan dan ajaran Islam militan... Buku-buku utama yang diisi dengan diskusi

20 New York Times. 2008. "Obama Remarks at AIPAC". Melalui <http://www.nytimes. com/2008/06/04/us/politics/04text-obama-aipac.html> [15/06/2017]

21 Robert F. Kennedy Jr. 2017. "AS Versus Arab di Suriah". Melalui <http://ic-mes.org/politics/ as-versus-arab-di-suriah-1/> [15/06/2017] 
tentang jihad dan gambar-gambar pistol, peluru, tentara, dan granat, telah masuk ke dalam kurikulum utama sekolah Afghanistan. Bahkan Taliban menggunakan buku-buku yang diproduksi AS." (Washington Post, 23 March 2002)

"Iklan-iklan, dibayar dengan dana CIA, dipasang di koran-koran dan newsletters di seluruh dunia, menawarkan bujukan dan motivasi untuk bergabung dengan Jihad [Islami]." (Pervez Hoodbhoy, Peace Research, 1 May 2005)

"Bin Laden merekrut 4000 sukarelawan dari negaranya sendiri dan membangun hubungan yang dekat dengan pemimpin mujahidin yang paling radikal. Dia juga berhubungan dekat dengan CIA, ... (Tapi) sejak September 11, [2001] pejabat CIA mengklaim bahwa mereka tidak memiliki hubungan langsung dengan Bin Laden." (Phil Gasper, International Socialist Review, November-December 2001) ${ }^{22}$

Dalam pernyataannya di depan Kongres AS, Menteri Luar Negeri AS saat itu, Hillary Clinton secara terbuka mengakui bahwa AS-lah yang mendanai Al Qaida. Terbentuknya Al Qaida adalah hasil kerjasama CIA dengan intel Arab Saudi dan Pakistan.

Di Suriah, AS juga mensponsori agenda penggulingan rezim Assad atas desakan Israel. Hal ini antara lain juga diungkapkan oleh Mearsheimer dan Walt dalam makalah mereka:

"Dimulai tahun 1990-an, dan khususnya setelah 9/11, dukungan AS kepada Israel telah dijustifikasi oleh klaim bahwa kedua negara diancam oleh kelompok-kelompok teroris yang berasal dari Arab atau Dunia Muslim dan oleh negara2 "kasar" yang mendukung kelompok teroris itu.... Ini juga berimplikasi bahwa AS harus menggulingkan rezim Republik Islam Iran, Saddam Husein di Irak, dan Bashar Assad di Syria.

22 Chossudovsky, Michel. 2010. "9/11 ANALYSIS: From Ronald Reagan and the SovietAfghan War to George W Bush and September 11, 2001." <http://www.globalresearch. ca/9-11-analysis-from-ronald-reagan-and-the-soviet-afghan-war-to-george-w-bushand-september-11-2001/20958> [1/6/2017] 
Israel dipandang sebagai sekutu penting dalam perang melawan teror karena musuh Isarel adalah musuh AS."123

Di bagian berjudul 'Menembak Suriah' (Gunning for Syria), Mearsheimer dan Walt menulis:

Segera setelah Baghdad jatuh di pertengahan April [2003], Sharon dan timnya mulai mendesak Washington untuk menargetkan Damaskus.... Sharon di Yedioth Ahronoth, menteru AS agar memberikan 'tekanan yang sangat berat' kepada Suriah. ...Para anggota Lobby Israel terkemuka juga menyuarakan argument yang sama setelah Baghdad jatuh. Wolfowitz menyatakan bahwa 'harus ada perubahan rezim di Suriah'. ... Pada 15 April [2003] Yossi Klein Halevi menulis artikel di Los Angeles Times berjudul "Selanjutnya, Kacaukan Suriah", dan hari berikutnya Zev Chafets menulis artikel di New York Daily News, "Negara Pendukung Teror, Suriah, Perlu Diubah Juga".24

Bahwa perang di Suriah menguntungkan Israel juga terlihat dalam berbagai pernyataan para pejabat Israel. Antara lain, Perdana Menteri Israel menyatakan, "Kami tidak akan membiarkan Israel diserang dari wilayah Suriah dan kami tidak akan menoleransi senjata canggih kepada Hizbullah melalui Suriah." Hal ini membuktikan bahwa posisi Suriah adalah berlawanan dengan Israel dan karena itulah Israel sangat berkepentingan dengan penggulingan rezim Assad. Selama masa perang sipil di Suriah, Israel merawat para petempur dari kelompok-kelompok 'jihad' Suriah di rumah sakit-rumah sakit mereka dengan alasan kemanusiaan ${ }^{25}$ serta melakukan berbagai serangan udara ke wilayah Suriah. ${ }^{26}$

Dengan demikian, dari dua faktor yang telah diuraikan, yaitu keterikatan ekonomi Arab-Barat serta posisi AS dalam hubungannya dengan Israel, kita

23 Mearsheimer, John J. and Walt, Stephen M. 2006. "The Israel Lobby and US Foreign Policy". London Review of Books Vol. 28, No. 6: 4

24 Ibid: 37

25 Jerusalem Post. 2015. "Israel treating al-Qaida fighters wounded in Syria civil war". Melalui <http://www.jpost.com/Middle-East/Report-Israel-treating-al-Qaida-fighters-woundedin-Syria-civil-war-393862>[15/6/2017]

26 Times of Israel. 2017. "Syrian rebels report fresh Israeli airstrikes near Damascus". Melalui <http://www.timesofisrael.com/syrian-rebels-report-fresh-israeli-airstrikes-neardamascus/>[15/6/2017] 
bisa melihat bahwa pada hakikatnya tangan negara-negara anggota Liga Arab yang terkuat (GCC) 'terikat', sehingga tidak bisa mengambil keputusan yang menyelamatkan anggotanya dari perang. Keputusan atau sikap yang diambil justru berpihak pada kepentingan AS dan Israel.

Selain itu, seperti terungkap dalam penelitian Nasur, et al. (2017) faktor kelemahan organisasional juga berperan dalam kegagalan ini. Sumber dari kelemahan organisasional adalah perbedaaan ideologi, terutama karena anggota Liga Arab tidak seluruhnya negara-negara yang terletak di jazirah Arab (sebagian berada di Afrika) sehingga memunculkan kerancuan geografi serta persaingan di antara etnik dan dinasti. Selain itu, seringkali draft keputusan Badan Liga di-'jegal' oleh konferensi negara dan misi-misi mediasi. Selain itu, secara organisasional, Liga Arab tidak menjalankan prinsip demokratis dan sering mengalami intervensi pihak asing sehingga tidak mampu mengambil keputusan unilateral demi kepentingan negara-negara Arab sendiri. ${ }^{27}$

\section{Kesimpulan}

Liga Arab didirikan dengan tujuan untuk melindungi kedaulatan masingmasing negara anggotanya serta peningkatan kerjasama di berbagai bidang, mulai ekonomi hingga kesehatan. Namun karena kawasan Timur Tengah selalui mengalami konflik, peran Liga Arab dalam meminimalisasi konflik sangat diharapkan. Tetapi sejak didirikannya hanya sedikit peran yang berhasil dimainkan Liga Arab dalam resolusi konflik. Bahkan di beberapa konflik kontemporer (Suriah dan Yaman), justru negara-negara kuat di Liga Arab yang menjadi aktor dalam konflik tersebut.

Dalam artikel ini telah dipaparkan dua faktor yang berperan dalam kegagalan Liga Arab memainkan perannya meminimalisasi konflik diTimteng.

Faktor pertama, eratnya kerjasama ekonomi dan saling ketergantungan antara negara-negara kaya Arab dengan AS. Kawasan Timur Tengah merupakan kawasan yang sangat kaya sumber daya minyak dan gas. Pada tahun 2007, kawasan ini memproduksi $36,7 \%$ total produksi minyak mentah dunia. Hal ini menjadi sumber ketergantungan negara-negara Barat, terutama

27 Nasur, et al. 2017. "The Failure of the Arab League in Solving Inter-State Disputes". Melalui < http://www.bjournal.co.uk/volume/paper/BJASS_22_1/BJASS_22_01_02. pdf $>[6 / 6 / 2017]$ 
AS, terhadap Timur Tengah dan karena itulah kebijakan luar negeri AS pasca Perang Dunia Il sangat memberikan prioritas terhadap keamanan aset minyak di Timur Tengah dan jalur distribusinya.

Ada 2 metode pendekatan AS terhadap keamanan minyak di Timur Tengah, yaitu:

1. Sejak tahun 1971, AS terus mempertahankan kehadiran angkatan lautnya di Teluk Persia demi menjaga keamanan distribusi minyaknya. Sebelum Revolusi Islam Iran tahun 1979, kehadiran angkatan laut AS di Teluk Persia berkoordinasi dengan pemerintah Iran dan Arab Saudi, yang disebut dengan 'kebijakan dua pilar'. Namun setelah hubungan AS-Iran memburuk pasca revolusi Iran, AS semakin memperkuat militernya di kawasan, dan kehadiran militer AS semakin intensif pasca Perang Teluk pertama tahun 1990-1991.

2. AS menjalin kerjasama yang erat dengan negara-negara kerajaan yang memiliki cadangan minyak yang besar, yaitu Arab Saudi, Kuwait, Bahrain, Qatar, Oman, dan Uni Emirat Arab. AS memaksimalkan kehadiran perusahaan-perusahaan minyak AS dalam proyek-proyek eksplorasi, refinasi, dan transportasi minyak dan gas di kawasan.

Faktor kedua adalah relasi kuat antara AS dan Israel sehingga AS sangat berperan memanfaatkan hegemoni ekonominya di tengah negara-negara Arab untuk membela kepentingan Israel. Hal ini terlihat jelas dalam konflik Suriah dimana negara-negara anggota Liga Arab terpecah dalam menyikapi Suriah yang sebenarnya anggota Liga Arab. Bahkan akhirnya Liga Arab mendukung agenda penggulingan rezim Suriah dan mengeluarkan Suriah dari keanggotaan Liga Arab. Selain itu, faktor kelemahan organisasional dan persaingan antarnegara menjadi faktor penyebab dari kegagalan Liga Arab untuk memainkan peran signifikan dalam menyelesaikan konflik Timur Tengah. 


\section{Call for Paper Jurnal ICMES Volume 1, No. 2}

ICMES (Indonesia Center for Middle East Studies) mengundang para pemerhati dan peneliti Timur Tengah untuk mengirimkan tulisannya di Jurnal ICMES Volume 1, No. 2dengan tema umum "Timur Tengah dan Terorisme". Sub-sub tema yang relevan antara lain sebagai berikut.

1. Genealogi Kelompok-Kelompok Terorisme di Timteng

2. Isu Terorisme dan Dinamika Hubungan Diplomatik Negara-Negara Timteng

3. Terorisme, Isu Kebangkitan Islam, dan Organisasi Transnasional

4. Terorisme di Timteng dalam Perspektif Ekonomi Politik Global

5. Jejaring Terorisme di Timur Tengah dan Dunia

6. Perempuan dan Terorisme

7. Dan lain-lain yang relevan.

Tulisan harap dikirim ke: icmes.indonesia@gmail.com paling lambat tanggal 28 Agustus 2017. Seleksi naskah akan melibatkan tim reviewer, yaitu para dosen Kajian Timur Tengah dari berbagai perguruan tinggi Indonesia. Penulis yang karyanya dimuat akan mendapatkan honor 1 juta rupiah.

\section{Syarat dan Ketentuan Penulisan Jurnal ICMES}

1. Artikel merupakan karya ilmiah orisinil yang belum pernah dipublikasikan.

2. Artikel ditulis dalam bahasa Indonesia.

3. Panjang tulisan sebanyak 5.000-6.000 kata.

4. Artikel meliputi : Judul, Nama lengkap penulis, Instansi penulis, Email, Abstrak, Kata-kata kunci, Pendahuluan, Landasan Teori/Metodologi, Pembahasan, Penutup/Kesimpulan, dan Daftar Pustaka.

5. Abstrak ditulis dalam bahasa Indonesia dan bahasa Inggris sebanyak 100150 kata.

6. Kata-kata kunci ditulis dalam bahasa Indonesia dan bahasa Inggris, maksimal 10 kata.

7. Referensi ditulis secara lengkap sebagai catatan kaki (footnote). Diharapkan referensi lebih banyak berasal dari jurnal ilmiah. Di akhir tulisan, daftar pustaka tidak perlu ditulis ulang.

8. Kata atau istilah yang belum diubah menjadi kata Indonesia diketik dengan huruf italic/cetak miring. 


\section{Aturan Penulisan Catatan Kaki (footnote)}

Pola penulisan catatan kaki adalah sebagai berikut (perhatikan ada yang harus dicetak miring, ada yang diberi tanda kutip).

\section{Buku}

Penulis (nama belakang, nama depan). Tahun. Judul. Kota Penerbit: Nama Penerbit. (halaman yang dirujuk).

\section{Jurnal}

Penulis (nama belakang, nama depan). Tahun. "Judul". Nama Jurnal. Volume/Edisi/ Nomer : halaman yang dirujuk.

\section{Artikel dalam website}

Nama penulis/nama media. Tahun. "Judul". Melalui a $<$ link artikel $>$ [tanggal/bulan/ tahun mengakses artikel]

\section{Contoh Catatan Kaki:}

\section{Buku:}

Mas'oed, Mohtar. 2009. IImu Hubungan Internasional. Jakarta: LP3ES. (139)

\section{Jurnal:}

Hermann, Charles F. 1990. "Changing Course: When Government Choose to Redirect Foreign Policy". International Studies Quarterly. Vol 34 No. 1: 12.

\section{Artikel dalam Website:}

Maarif, Ahmad Syafii. 2016. “Erdogan VS Gulen, Bencana Politik Bagi Turki”. Melalui <http://maarifinstitute.org/id/serambi-buya/opini-buya/268/erdogan-vs-gulenbencana-politik-bagi-turki-i\#.WE6joLlteUk> [19/11/2016]

Tempo. 2016. “Dukung Palestina, Menteri Retno Resmikan Konsulat Kehormatan". Melalui<https://m.tempo.co/read/news/2016/03/10/078752480/dukungpalestina-menteri-retno-resmikan-konsulat-kehormatan> [19/11/2016]

WTO. 2004. "The Agreements". Melalui <http://www.wto.org/english/thewto_e/ whatis_e/tif_e/utw_chap2_e.pdf.> [15/10/2014]

\section{Artikel dalam majalah/koran edisi cetak:}

Baswir, Revrisond. Harian Kedaulatan Rakyat. 26 Juni 2009. "Boediono dan Neoliberalisme". 